DOI https://doi.org/10.36059/978-966-397-233-6-9

Валерій Ластовський

\title{
Наукова міфологізація історії Черкащини та проблеми ї̈ подолання
}

\section{Scientific mythologization of the history of Cherkasy region and problems of its overcoming}

The question of the emergence and spread of scientific myths in the history of Cherkasy region has been considered for the first time. Some of these myths are local in nature, but some have already become part of the overall narrative within Ukraine and beyond. Without reflecting real historical facts and events, they, accordingly, distort the past. The emergence of these myths is due to various circumstances: sometimes as a result of confusion, sometimes as a result of an attempt to explain an incomprehensible phenomenon or event, sometimes as a result of direct falsification. The longevity of these myths can only be explained by the lack of in-depth research and the survivability of certain stereotypes, the use of which greatly simplifies the perception of the past. The maintenance of scientific myths is typical for many scientists, who themselves are their creators and keepers.

The first myths related to Cherkasy region are already recorded in the 16 th century. Since then, Cherkasy has become the center of this region. And this is what almost the largest number of delusive ideas concern. Most of them concern the emergence of the city, the origin of its inhabitants, individual place-names and various events and facts. The biggest myth perceived by the population, supported by both scholars and the authorities, is the myth of the 700th anniversary of Cherkasy, which was finalized in 1986. A significant number of historical myths are also connected with other settlements of Cherkasy region. Most of them concern the emergence of villages and towns, local names, the activities of monasteries and clergy, the history of the Ukrainian Cossacks (for example, in relation to Kaniv, Trakhtemirov, Chyhyryn region, etc.).

The reasons for the emergence of such myths are determined by both personal and more general factors. Identifying and uncovering myths is another important area of scholarly work that needs to be discussed and covered. After all, scientific myths are a distortion of the idea of society and its nature. Since Cherkasy region is no exception to the existence of myths among all other regions of Ukraine, the scale of their spread is becoming very large. 
Міфологізація історії Черкащини має не лише суто регіональне значення. Ситуація із цим краєм притаманна багатьом іншим регіонам України. Значна частина тих історичних міфів, про які ми можемо говорити, має широке використання; вони побутують не лише в регіональних публікаціях, а й загалом в українській (у т. ч. діаспорній), польській та російській історіографії. Але важливо звернути увагу на ту обставину, що ці історичні міфи, сформувавшись у локальному середовищі, знаходять своє поширення серед пересічних громадян, стають "хрестоматійними” для підручників, наукових публікацій тощо. Відповідно, під впливом цих міфів формується і викривлюється історична пам'ять усього народу.

В історіографії приділялася увага викривленню історичного простору як науковцями, так і краєзнавцями. Але, як правило, лише в окремих випадках. Загалом питання щодо з'ясування проблеми міфів на Черкащині в історичній науці ще не ставилося і не розглядалося. Але слід відзначити, що окремі епізоди, присвячені розгляду міфів, можна побачити в працях дослідників, починаючи ще від XIX ст. і до сучасності, зокрема, у публікаціях Михайла Максимовича, Володимира Антоновича, Андрія Яковліва, Юрія Мариновського, Дмитра Куштана та ін.

Початки міфологізації історії Черкащини простежуються вже від XVI століття. Тоді вперше з'являються ідеї щодо походження міста Черкаси, засновані не на історичних фактах, а на бажанні пояснити певне явище шляхом спрощення та здобути при цьому ще й певну матеріальну вигоду (це видно на прикладі “канівської легенди”). У подальшому на території Черкащини поступово почали з'являтися нові історичні міфи. Тісно пов'язані з соціально-політичними процесами, міфи повинні були сприяти укріпленню позицій певних суспільних верств - шляхти, козацтва, духовенства. Від XIX ст. міфологія почала вже набувати “наукового" обгрунтування. Але міфотворчість властива також для XX і навіть для XXI століття.

Здавалось би, наявність історичних міфів суперечить суті наукового підходу до висвітлення історичних процесів. А втім, слід зазначити, що значною мірою ці міфи поширюються саме через наукове середовище. Причинами цього є: 1) неправильне 
тлумачення джерел, 2) відсутність переконливої джерельної бази, 3) особиста зацікавленість у вирішенні питання "за власним сценарієм".

Можна виділити кілька груп історичних міфів Черкащини, що були створені за різних обставин: 1) міфи, пов'язані з появою та розвитком самого міста Черкаси; 2) міфи, пов'язані з історією окремих населених пунктів та місцевостей; 3) міфи, пов'язані з персоналіями.

Звісно, можна здійснювати класифікацію міфів за іншими критеріями. Всі міфи, які створюються, можна також поділити на дві групи: 1) міфи, що мають локальний характер; 2) міфи, що мають загальнонаціональний характер. Останні набувають поширення на всьому державному просторі та навіть за його межами.

Найзначніша група історичних міфів пов'язана із містом Черкаси як центральним пунктом всього регіону. I левова частина їх стосується проблеми походження і появи міста. Слід підкреслити, що це питання не має суто утилітарного знання задля відповіді на питання “хто і коли?” Насправді воно має цивілізаційний контекст. Адже його можна розглядати або як результат впливу східних елементів, або ж як наслідок діяльності європейської цивілізації...

Зацікавлення питанням щодо появи міста ми знаходимо ще y XVI-XVII ст. Його намагалися пояснити як місцеві жителі (канівський боярин Чайка), так і іноземці (Сигізмунд Герберштейн, Евлія Челебі). А вже в XVIII ст. російськими істориками Василем Татіщевим та Іваном Болтіним була сформована концептуальна база під майбутню офіційну позицію щодо 700-річчя міста. Останнє і стало найбільшою штучно створеною містифікацією. Сталося це виключно завдяки офіційній підтримці владних та партійних органів у 1980-х роках (Куштан, Д. \& Ластовський В., 2016, с. 157).

Оскільки питання походження Черкас дуже цікавило і науковців, і місцеве населення, при цьому багатьох не влаштовувала ані офіційна версія, ані навіть близькі до неї варіації, то створювалися інші різноманітні міфи щодо появи міста: Черкаси - ровесник Шумеру, Черкаси - скіфський Гелон, Черкаси - давньоруський 
Родень і т. п. Зрозуміло, засновниками також називалися різноманітні етнічні та соціальні групи (відповідно до кон'юнктурних коливань): узагальнені чорні клобуки, черкеси, касоги, татари, біглі селяни, автохтонне населення, козаки і навіть міфічні “чернъаси”, яких насправді ніколи не існувало. Уже під ці міфи про засновників підтягувалися обгрунтування деяких топонімів - Кавказ, Казбет, Бешта. В багатьох публікаціях їхнє існування визначалося як підстава для заснування Черкас переселенцями з Кавказу. Хоча насправді ці назви почали з'являтися лише в кінці XIX - на початку XX ст. зовсім з інших причин.

Спотворюючи одну інформацію, дослідники (свідомо та/або несвідомо) досить часто дозволяють собі ігнорувати іншу, забуваючи про необхідність комплексного підходу до розгляду питання. Наприклад, майже завжди ігнорувався такий давній топонім як “Чехове́/Чехова́” (згадується ще в документах XVI ст.), що зберігся до нинішнього часу у вигляді назви вулиці Чехова. На жаль, завдяки політиці радянської влади та позицій місцевих краєзнавців, ця назва на сьогодні вже автоматично ототожнюється з іменем відомого письменника Антона Чехова, який насправді не мав до неї жодного відношення.

Так само багато існує на Черкащині й історичних міфів, пов'язаних з історією інших населених пунктів. Наприклад, вважається, що село Водяники було засноване у XIV ст. (тільки на підставі того, що в його околицях було знайдено скарб джучидських монет), що нинішня Сміла - це літописний Кульдур, що в районі села Дахнівка існувала найперша козацька Січ і т. д.

Між іншим, творцем Дахнівської Січі був польський історик Едвард Руліковські. У сучасну історію цей міф увійшов уже в 1990-х роках, коли він вперше виринув на сторінках черкаської преси. А остаточно його формування завершилося з розпорядженням міського голови Черкас від 27 січня 2016 р., яким за результатами роботи Топонімічної комісії було затверджено перейменування вулиці Ворошилова на вулицю Дахнівська Січ. У мотиваційній частині було зазначено: “Одна з перших січей у XVI ст. біля села Дахнівка, а вулиця розташована у його старовинній частині. Унікальна Черкаська назва". Сама мотиваційна частина містить наступні неправдиві свідчення: 
1) “Одна з перших січей у XVI ст.”. Насправді ніякої Січі тут ніколи не існувало. Це не підтверджується (навіть на гіпотетичному рівні!) жодними можливими історичними джерелами. Перелік козацьких Січей відомий, інших не існувало; 2) “...біля села Дахнівка”. У XVI ст. села Дахнівка ще не існувало (воно з'явилося тільки у XVIII ст.), а на момент перейменування це вже була територія міста Черкаси, а не села (від 1982 р.); 3) "Унікальна Черкаська назва". Унікальною назва стала лише від моменту їі узаконення 27 січня 2016 р., тому що до цього часу такої назви не існувало!

Звідки ж взявся цей міф? Основою для нього послужили слова відомого польського історика Едварда Руліковського (1825-1900), опубліковані 1880 р. в статті “Czerkasy” (Rulikowski E., 1880, s. 802-808). Зокрема, в ній було зазначено: “Інші ж заявляють, що давня Січ запорозька була раніше коло Черкас, за селом нинішнім Дахнівкою, але як швидко залюднилося, то мешканці їі перенесли до Кременчука, а коли і там все залюднилося, то тоді тільки перенеслися вони на Низ і від того часу Запорожцями прозвалися. То може бути який-небудь народний вимисел, одначе ж він може містити й частку правду" (Rulikowski, E., 1880, s. 803). Навіть із цього тексту випливає, що сам Е. Руліковський ставився до інформації про Дахнівську Січ не більше ніж як до якогось народного вимислу, підтвердження якому не було. Він писав, що, за переказом, “січ” знаходилася десь за селом, а не біля нього.... Де і від кого він почув цей переказ наразі невідомо. Можливо, це сталося під час Археологічного з'їзду у Києві (1874), учасником якого був дослідник, а, можливо, і в якийсь інший спосіб. У будь-якому разі сам він в Черкасах ніколи не бував і з місцевим населенням, відповідно, не спілкувався. Принагідно тут можна зауважити, що єдиною людиною, яка цілеспрямовано займалася опитуванням місцевих жителів у XIX ст. і записувала їхні перекази про минуле, був Пантелеймон Куліш (1819-1897). 1856 р. його записи увійшли до книги “Записки о Южной Руси”. Проте, в ній немає жодного переказу про “січ” за Дахнівкою.

Окремо варто сказати за назву “Дахнівська Січ”. Якщо розглянути усталені назви всіх відомих козацьких Січей, то вони 
завжди були прив'язані до того топоніму, який реально існував на момент існування самої Січі (Хортиця, Базавлук, Чортомлик i т. д.). Але назва "Дахнівка" виникла лише у XVIII ст. Між іншим, за логікою творців міфу про Дахнівську Січ, слід було б розвивати ідею про існування ще також і Кременчуцької Січі (оскільки про це написано у того ж таки Е. Руліковського).

Окремо слід зупинитися на персоналіях в історії Черкаського краю. Як показує аналіз життя і діяльності багатьох історичних осіб, в наукових та краєзнавчих публікаціях присутня значна кількість “фактів”, яких насправді не було або ж вони мали зовсім інший характер.

Так, “черкаський протопіп Федір Гурський” $€$ вигаданим персонажем. Вперше інформація про нього з'являється у відомій історичній пам'ятці початку XIX ст. “Історія русів" (опублікована у 1846 р.). I звідси починається її поширення по інших історичних творах. Потім, запозичивши майже дослівно цю інформацію ще з рукопису “Історії русів", її опублікував відомий український історик Микола Маркевич (1804-1860) у 1842 році у своїй “Истории Малороссии” (Маркевич, Н., 1842, с. 257). Далі, у 1844 році, за цими ж мотивами Тарас Шевченко написав свій відомий офорт “Дари в Чигирині”.

Автор "Історії русів" досить детально описав сцену прийому іноземних послів гетьманом Богданом Хмельницьким і тих подарунків, які йому були ними піднесені. Відніс він цю подію до травня 1650 р. Оригінальне повідомлення в “Історії русів" звучало наступним чином: “Духовенство Малоросийское, большею частию обращенное из униятства и крайне сожалевшее втайне о потерянной его власти над народом, поданной было им поляками и близкой к рабству, сплело нелепую басню в разсуждении посольства московскаго и всех прочих, и бывший с ним в собрани протопоп Черкаский, Федор Гурский, почитавшийся в народе отличным богословом и проповедником, взявши текст из священного Евангелия и употребляя его на зло самым странным сравнением, говорил в собрании, что, “как, де, от трех царей или волхвов поднесенные младенствующему Христу дары: злато, ладан и смирна, предзнаменовали бытие и страдание его в мире и возвращение в небо, то есть, злато значило Царя, 
ладан мертвеца, а смирна показывала Бога, то так и сии дары, подносимые от Царей народу, предзнаменуют, чем они одеты или покрыты, в том будет жить или покрываться народ, ими прельстившийся, на пример: дары польские состоят в сукнах, покрытых ковром, то будет и народ, с поляками живший, ходить в сукнах и иметь ковры; турецкие дары одеты и прикрыты бумагою и шелком, то и народ, за ними живший, будет в состоянии одеваться шелковыми и бумажными материями; а Московские дары суть все в рогожах, то неизбежно и народ, живучи с ними, доведен будет до такой бедности, что уберется он в рогожи и под рогожи. И эти заключения суть верны и превосходят всех оракулов в свете" (История русов, 1846, с. 98).

Тепер вже важко з'ясувати, звідки в “Історії русів" з'явилися цей персонаж і його промова. Цілком очевидно можна сказати тільки наступне:

- оригінальні джерела не підтверджують існування черкаської протопопії як церковної структури у середині XVII ст.;

- оригінальні джерела не підтверджують існування в цей час будь-якого священика Федора Гурського;

- оригінальні джерела навіть не підтверджують подібної наради, на якій хоча б теоретично міг виступити подібний персонаж;

- оригінальні джерела не підтверджують навіть народних переказів подібного змісту.

Чи міг бути хоч теоретично якийсь прототип для зазначеного персонажа? Звісно, що міг. На цю роль може претендувати, наприклад, посланець єрусалимського патріарха Федір Грек (чим не Федір Гурський?), який у 1655 р. разом із козацьким посольством (яке поверталося із Стамбула) приїхав спочатку до Богдана Хмельницького, а потім вже вирушив до Москви. I саме перед московським царем він розповідав про багаті дарунки від султана козацькому посольству, а щодо польського - то навпаки - їх було “відправлено з нічим".

На сьогодні слід відзначити дуже плідну роботу щодо вивчення персоналій Черкащини, проведену істориком Дмитром Куштаном. Ряд його наукових розвідок дозволив з'ясувати, що черкаськими полковниками у XVII ст. не були Іван 
Барабаш, Максим Кривоніс, Петро Дорошенко, Федір Вешняк, Денис Мурашко... (Куштан, Д., 2019) А їх, між іншим, постійно вказували серед очільників Черкаського полку і навіть приписували їм певні організаційні дії на цій посаді. Те ж саме дослідник вказує і з приводу таких “старост” черкаських, як Василь Загоровський та Ярема Вишневецький.

Окремо слід вказати на “хрестоматійне” ототожнення діяльності князя Дмитра Байди-Вишневецького з Черкасами. Це стосується відомих “істин”, що він у 1550-х роках: 1) перебував на посаді старости черкаського і канівського та 2) захопив міста Канів і Черкаси з метою передачі їх московському царю Івану IV. Насправді ж цього всього не було. Більше того, навіть не відомо, чи хоч один раз Дмитро Байда-Вишневецький тут побував (Ластовський, В., 2018).

Ряд міфів існує стосовно ще однієї історичної особи, пов'язаної з Черкащиною - старостою черкаським і канівським (цього разу справжнім!) Остафієм Дашковичем (помер 1535 р.). Зокрема, в літературі постійно поширюється уявлення про його татарське, князівське походження (від князів Глинських), гетьманство над козацтвом тощо. Остання містифікація з'явилася лише кілька років тому, відповідно до якої Остафій Дашкович займався фальшуванням монет у Каневі та Черкасах. Підставою для такої думки послужили деякі знахідки (навіть не масові) фальшивих монет початку XVI ст. (Ластовський В., 2013).

Чому і яким чином створюються міфи? На це питання достатньо важко відповісти, в кожного випадку - своя історія. I не завжди зрозуміло, що стає їхньою першопричиною: уява, помилка чи щось інше... Але з часом новостворені міфи широко тиражуються, тому що подобаються або оригінальністю, або тим, що заповнюють лакуну відсутньої інформації... Так сталося з багатьма подіями в історії. Наприклад, можна згадати ситуацію з трактуванням щодо перебування в Черкасах (чи біля них) хана Тохтамиша або ж ситуацію з питанням щодо оборони Черкас під час нападу кримських загонів у 1482 році...

Щодо хана Тохтамиша, який раптово поселився чи в самих Черкасах, чи десь під Черкасами 1396 (або 1398) року, інформація 
в український науковий простір увійшла 1993 року після публікації Наталією Яковенко її прекрасної монографії “Українська шляхта з кінця XIV до середини XVII ст.” I там, між іншим, у контексті теорії авторки було написано: “...хвилі переселенців почали прибувати в Україну з часів Тохтамиша, котрий зі своїм двором в часи боротьби з Темір-Кутлуєм за Крим утік на Наддніпрянщину. Для нього і його васалів восени 1396 р. Вітовт виділив землі на південному прикордонні, зокрема у Черкасах і Каневі" (Яковенко Н., 1993, с. 174). І далі вона зробила покликання на книгу Олександра Барбашева "Витовт и его политика до Грюнвальдской битвы 1410 г.” (СПб., 1885), за яку той отримав ступінь магістра російської історії (1886). Потім Н. Яковенко повторила вищенаведену інформацію і у 2-му виданні свої книги у 2008 р., виправивши лише дату - на 1398 р. Уточнення, яке все ж таки немає принципового значення. Та справа в тому, що насправді немає жодної подібної інформації навіть про можливість проживання Тохтамиша під Черкасами, не кажучи вже про реальність.

Можливо, творцем висловленої ідеї став сходознавець, доктор історичних наук, професор Магомет Сафаргалієв (1906-1970), у якого 1960 р. в мордовському видавництві в Саранську видана монографія “Распад Золотой Орды”. Там міститься наступний текст: “Витовт, поддерживавший дружественные отношения с Тохтамышем, принял хана и прибывших с ним татар с почетом: татарам были выделены места для жительства в пограничных районах государства, в частности в Черкасах и Каневе" (Сафаргалиев М., 1960, с. 178). I далі йде знову покликання на працю Олександра Барбашева (щоправда, написано було чомусь “Барабашов”).

Цікаво те, що у згаданій праці Олександра Барбашева насправді немає жодної згадки ані про Черкаси, ані про Канів. Можна навести лише кілька цитат з його твору, що стосуються всієї цієї ситуації у взаємовідносинах Вітовта і Тохтамиша:

1) “Витовт дружелюбно принял Тохтамыша, расчитывая с его помощью расширить свои владения на восток” (с. 94);

2) “...летом 1398 года... Витовт построил крепость Ивановскую (в нижнем течении Днепра) и увел в Литву много пленных татар, которых и поселил коло Вильны” (с. 95). 
Оце й усе. Залишається загадкою, чому М. Сафаргалієв (а за ним, вочевидь, і Н. Яковенко) саме так сформулював свою думку. Можливо, він це вважав логічним, можливо, з інших міркувань...

Про всяк випадок розглянемо літописні джерела. Ось запис у 2-му Софійському літописі за 1398 рік: “...А Тахтамыш сослался с Витовтом, прибежа в Киев, со двема сыны и царицами” (ПСРЛ, 1853, с. 130). Таку ж інформацію знаходимо і у Воскресенському літописі (ПСРЛ, 1859, с. 71). I, до речі, тут все цілком логічно: Тохтамиш з'являється в Києві, а не в нікому невідомих на той час Черкасах...

3 явною помилкою пов'язане і уявлення про оборону Черкас 1482 року. Відомий історик Михайло Владимирський-Буданов (1838-1916) 1890 року написав: “Черкаський замок... у 1482 році... не тільки уцілів, але черкащани, під керівництвом Матвія Кмити, розбили татар" (Владимирский-Буданов М., 1890, c. 83-84). Згодом ця позиція повторювалася у багатьох наукових та краєзнавчих публікаціях. I чомусь ніхто навіть не поставив питання: як могло статися, що внаслідок нападу орди зруйновано значно могутніший Київ, а маленьке поселення вціліло? На жаль, впевненість авторів тих публікацій у героїзмі місцевих жителів, яка повторювалася із публікації в публікацію, залишається лише в рамках їх фантастичних уявлень. А от документальне свідчення від самого хана Менглі-Герая у листі до великого князя московського Івана III 1495 року свідчить зовсім про іншу ситуацію: “...місто Київ спалив я, Хотковича Івашка пана 3 жінкою і з дітьми у полон взяли; Черкаське містечко йшовши спалив я..." (Сборник ИРИО., 1884, с. 218). Це повідомлення стосується конкретних подій 1482 року і ніяких інших. На це вказує те, що їх перераховано в одному контексті, де Менглі-Герай звертається до Івана III з нагадуванням про союзницькі стосунки, спільні інтереси і дії, виявом яких і був напад на Київ і Черкаси у 1482 році.

Серед значного розмаїття інших історичних міфів Черкащини можна назвати такі найпоширеніші міфи:

- існування кам'яного замку Дмитра Вишневецького в Черкасах; 
- існування Ірдинського, Трахтемирівського та Канівського монастирів у XVI ст. (а то й раніше, та ще й з печерами);

- передача Трахтемирівського монастиря козацтву королем Стефаном Баторієм;

- козацькі могили у Трахтемирові та поховання Івана Підкови, Якова Шаха і Самійла Кішки у Канівському монастирі;

- заснування Мотронинського монастиря княгинею Мотроною;

- існування Зарубського монастиря в часи Русі, з якого вийшов і став київським митрополитом Климент Смолятич.

В окремих випадках, але не завжди, розглядаючи походження історичного міфу, можна визначити причини його виникнення. Наприклад:

1) у випадку з Мотронинським монастирем - це всього лише знахідка візантійської монети з літерою “М”, яка означала їі номінал, але яка була сприйнята як початок імені “Мотрона”;

2) у випадку з Зарубським монастирем - це спрощений підхід до пояснення зв'язку між археологічними знахідками і документальними джерелами;

3) у випадку з 1482 роком - помилка Довнара-Запольського, який пропустив інформацію з листа Менглі-Герая;

4) у випадках із “козацькими міфами” - це, безпосередньо, ідеологічні уявлення Самійла Величка та Григорія Грабянки, які, проте, спиралися все ж таки на певну інформацію з польської літератури, але при цьому узагальнювали її та створювали своє бачення;

5) у випадку з назвою вулиця Чехова́, яку перетворили на Че́хова - це вже пряма фальсифікація.

На жаль, історичні міфи відзначаються живучістю навіть у тих випадках, коли вони вже детально розкриті і спростовані. Але сама ідея міфу, як виявляється, настільки подобається, що iї продовжують і далі підтримувати. Зрозуміло, цьому сприяє достатньо вузьке поширення наукової інформації. Наприклад, це стосується міфу про заснування Мотронинського монастиря княгинею Мотроною, який був розвінчаний і пояснений ще на початку XIX століття, міфу про Татинець, який був розвінчаний ще Михайлом Максимовичем, міфу про Дмитра Вишневецького 
як старосту черкаського і канівського, який був спростований ще 1907 р. Андрієм Яковлівим, міфу про “чернъаси”, спростований Юрієм Мариновським і т. д.

До того ж ці міфи ще й мають своє продовження. Наприклад, згаданий міф про Татинець знайшов своє продовження в тому, що 2016 року в Черкасах одну з вулиць було перейменовано на Татинецьку.

До творення історичних наукових міфів долучаються навіть дуже знані і авторитетні науковці. Яскравий приклад - це міф про 700-річчя Черкас. Звісно, що ця ідея визрівала у досить широкому партійному просторі 1980 -х років. Але остаточно благословив його відомий історик Борис Рибаков своєю “Науковою запискою" 1985 року, затвердженою Інститутом археології АН УРСР. Можна, звичайно, цей акт виправдовувати вузьким колом відомих на той час джерел. Та насправді навіть відоме коло джерел на той момент не давало права на відповідний висновок! Це рішення мало не науковий, а суто партійний характер...

Нещодавно вийшла з друку об’ємна книга “Черкащина. Історія краю та його людності” (2017). Новий матеріал. Нові факти. Нові підходи у висвітленні багатьох проблем. Але, на жаль, багато в чому черкаські дослідники: 1) повторили ті міфи, які існували, a 2) деякі міфи вони просто обійшли, залишивши на розсуд читача, вірити їм чи ні. Останній підхід, звичайно, не можна вважати конструктивним.

I одна з сучасних проблем полягає в тому, що самі історики дуже важко відпускають міфи від себе. Хтось - в силу ідеологічних моментів, хтось - в силу суб'єктивної переконаності (навіть якщо вона суперечить об'єктивно існуючим фактам).

Чи можуть міфи завдавати шкоди? Це питання до певної міри риторичне. Звісно, на значну кількість міфів можна дивитися як усього лиш на певний пережиток. Але деякі міфи мають більш глобальний характер. Вони реально спотворюють розуміння історичного процесу. Зокрема це стосується міфу про 700-річчя Черкас і про зв'язок назви міста із “черкесами”. Адже цей міф дає можливість заперечувати належність Середнього Подніпров'я до європейського простору. Цей міф став основою для тверджень багатьох російських істориків ще від XVIII ст. 
про варварський характер українського козацтва. Він став основою для теорії про “велику Черкесію” (Хотко), яка охоплювала межі від Кавказу до Дніпра. Насправді ж Черкаси творилися виключно як європейський форпост. Вся відома рання історія міста пов'язана не з черкесами чи татарами, а з очільниками форпосту, які походили з польських родів: пан Бедрих із Сілезії, пан Рафал із Слупова. Візьмемо до уваги, що і вся реальна історична інформація пов'язана з часом князів Коріатовичів, а не з кимось іншим. Взагалі, $є$ всі підстави вважати, що у XIV ст. існував генетичний зв'язок із вихідцями з Карпато-Дністровського регіону.

Ще одним фактором спотворення історичної інформації $\epsilon$ вживання (у т. ч. багатьма науковцями) невідповідної термінології. Маю на увазі передовсім такі поняття як “козацькі монастирі”, “оборонні монастирі”, “козацькі цвинтарі” і т. д. Насправді такі терміни спотворюють справжній зміст відповідних явищ.

У нашій розповіді ми можемо спостерігати ще й своєрідний ефект доміно, відповідно до якого поява одного міфу спричиняє подальшу появу нових міфів, які є чи своєрідним продовженням, чи доповненням до попередніх. Це ми можемо бачити як на прикладі міфів, пов'язаних із заснуванням Черкас, так і на прикладі “козацьких монастирів” у Каневі та Трахтемирові.

Отже, можна стверджувати, що міфологізація минулого займає досить значний сектор у наукових та краєзнавчих публікаціях, в історичній пам'яті населення як певного регіону, так і всієї України. Від цього залежить уявлення про місце наших земель у цивілізаційних процесах на теренах Східної Європи. При цьому не існує проблеми, якої не можна було б вирішити. Тому історичні міфи стосовно Черкащини варто розглядати та обговорювати. Для цього необхідно, перш за все, бажання самих вчених, широке висвітлення їх напрацювань, обговорення відповідних проблем на конференціях, активна комунікація із населенням та владою.

\section{Література}

Владимирский-Буданов, М. 1890. Население Юго-Западной России от второй половины XV в. до Люблинской унии (1569 г.). Архив Юго-Западной России. Часть VII. T. II. Киев. 
История русов. 1846. Москва.

Куштан, Д. 2019. Полковники Черкаського полку Війська Запорозького (від заснування до 1652 року). Нові дослідження пам'яток козацької доби в Україні. Вип. 28. Київ.

Куштан, Д. \& Ластовський, В. 2016. Археологія та рання історія Черкас. Київ-Черкаси.

Ластовський, В. 2013. 3 приводу фальшування литовських півгрошей Остафієм Дашковичем. Наукові записки з української істоpiï. Вип. 33. Переяслав-Хмельницький.

Ластовський, В. 2018. Дмитро Байда-Вишневецький і Черкаси: міфи в історіографії. Нові дослідження пам'яток козацької доби в Україні. Вип. 27. Київ.

Маркевич, Н. 1842. История Малороссии. Т. І. Москва.

Полное собрание русских летописей (ПСРЛ). 1853. Т. 6. Санкт-Петербург.

Полное собрание русских летописей (ПСРЛ). 1859. Т. 8. Санкт-Петербург.

Сборник Императорского руського исторического общества (Сборник ИРИО). 1884. Т. 41. Санкт-Петербург.

Сафаргалиев, М. 1960. Распад Золотой Орды. Саранск.

Яковенко, Н. 1993. Українська шляхта з кінця XIV до середини XVII ст. Київ.

Rulikowski, E. 1880. Czerkasy. Słownik Geograficzny Królestwa Polskiego i innych krajów słowiańskich. T. 1. Warszawa. 